\title{
Examining Pre-Service Teachers' Nomophobia Levels in Terms of Several Variables
}

\author{
Gökçe BECITT İ̧ÇiTÜRK ${ }^{1}$ \\ ${ }^{1}$ Faculty of Education, Nevşehir Hacı Bektaş Veli University, Nevşehir, Turkey \\ Correspondence: Gökçe BECITT İşÇITÜ̈RK, Faculty of Education, Nevşehir Hacı Bektaş Veli University, \\ Nevşehir, Turkey. E-mail: gokcebi@nevsehir.edu.tr
}

Received: July 29, 2020 Accepted: October 1, 2020 Online Published: October 23, 2020

doi:10.5539/jel.v9n6p21 URL: https://doi.org/10.5539/jel.v9n6p21

\begin{abstract}
This study aims to determine the nomophobia levels of pre-service teachers, the variables affecting their nomophobia levels, and the relationship between the levels of nomophobia and cyberloafing. The study, which was designed as a correlational study, was conducted with the voluntary participation of 666 pre-service teachers. The data of the study were collected using a personal information form, the Nomophobia Scale (NMP-Q), and the Cyberloafing Scale. The results showed that 528 students $(79.3 \%)$ had a moderate and high level of nomophobia while 138 students $(20.7 \%)$ had a low level of nomophobia. As a result of the analyses conducted to determine whether the nomophobia levels of teacher trainees differed depending on gender, it was seen that the nomophobia level of women was statistically higher than that of men. It was concluded that the nomophobia levels of the pre-service teachers did not vary depending on the level of education and their experience of using smartphones. Although, the results gathered from the first analysis results indicated that the nomophobia levels of the pre-service teachers depicted difference concerning the departments at which they studied, this difference proved insignificant as indicated by the anteceding detailed analyses carried out. It was concluded that the nomophobia levels of the pre-service teachers differed significantly depending upon the amount of time they spend on social media. The last finding of the study concluded that cyberloafing significantly predicted nomophobia levels of pre-service teachers. Based on this result, it can be said that the pre-service teachers' cyberloafing behaviors will increase their tendency to exhibit nomophobic behaviors. For further research, mixed studies in which qualitative methods will also be used to obtain more in-depth data can be designed. It was also found out that the nomophobia levels of the pre-service teachers differed significantly based on their daily social media usage time.
\end{abstract}

Keywords: nomophobia, pre-service teachers, cyberloafing, problematic ICT use

\section{Introduction}

The rapid developments in information and communication technologies (ICT) have affected the mobile phones that we commonly use in communication processes in all areas of our lives. The eminence and the effect of the mobile phones, which have broadened their "once sole" function as a means of communication owing to their improved processors, cameras, and especially the integration of the internet into it, and which can not only function as a telephone, but also a computer, and which are now named "smartphones", have been immensely rising. The percentage of houses that had mobile phones/smartphones had risen to $98.7 \%$ in 2018 (TUIK, 2018). Likewise, in line with the We Are Social Digital 2019 report, which is annually published by We Are Social and Hootsuite, and which gathers together and compiles digital data, the proportion of mobile device use to population was $73 \%$ in 2017 whereas it rose to $93 \%$ in 2018 . The intense use of smartphones to such extent has made the Internet accessible at any time. As their functionality and capabilities are increasing, so are the problems associated with mobile phones and their negative effects on individuals (Hong, Chiu, \& Huang, 2012). Although through mobile phone applications that we use sometimes as a bank, sometimes as a mall, and sometimes as a library, our lives are getting more convenient, some of the disadvantages and illnesses that might be caused by these smartphones in the spheres of our daily life and educational environments are addiction, attention-deficit, empathy disorder, decrease in academic success due to disrupted learning, hypertension, obesity, anxiety, depression, personality disorder, anger, insatiateness and loneliness (Adnan \& Gezgin, 2016). "Problematic smartphone use" (Billieux et al., 2010, p. 602) has brought about concepts such as smartphone 
addiction (Lin et al., 2014), nomophobia (Dixit et al., 2010), cyber-bullying, and cyber-loafing, which have been examined by researchers.

"Nomophobia" is a new concept, and the word is made up of the abbreviated forms of the English words, "no-mobile-phone-phobia". This new concept points to the excessive and problematic use of mobile technologies (Yıldırım, 2014, p. 6; Gezgin, Şahin, \& Yıldırım, 2017). Accompanied by improving and expanding technology, smartphones have been the reason why nomophobia has been attributed to a phobia of modern times (Ylldirım \& Correia, 2015). Nomophobia is defined as the unreasonable fear and anxiety that an individual experiences when $\mathrm{s} / \mathrm{he}$ is unable to reach her/his mobile device or communicate via it (King, Valençe, \& Silva, 2013). Some of the symptoms to typically be observed on a nomophobic individual may be listed as never turning off the phone during the day, spending too much time using and frequently checking the device out for its prospective updates and the messages that might have been conceived. Besides the pre-mentioned physically observable symptoms, a nomophobic person embeds the constant fear of losing the smartphone, not being nearby it, not being able to locate it, being out of its range, and is running out of battery; and this way, mobile units create concern for this person (Bragazzi \& Pente, 2014; Erdem, Turen, \& Kalkın, 2017).

Nowadays, smartphones have become an important part of our techno-culture, especially among the younger population, whose primary need is to socialize, to join in, and to be liked (Pavithra, Suwarna, \& Murthy, 2015). When research projects in which the nomophobia frequencies of individuals were studied were examined, it was concluded that this frequency in Turkey was $42 \%$ among university students (Ylldırım et al., 2016), and 73\% among high school students (Gezgin, Çakır, \& Yıldırım, 2016); and that the nomophobia levels of general social network users were above the average (Gezgin, Şahin, \& Yıldırım, 2017). Although different averages have been found out in various studies conducted with university students, it can be said that in general, university students have moderate and high levels of nomophobic behaviors (Yildırım et al., 2015; Adnan \& Gezgin, 2016; Burucuoğlu, 2017; Turan \& Becit-İş̧̧itürk, 2018).

In the present era, when lots of people have been using mobile phones as an indispensable part of their lives, people have also begun to grow an undeniable fear of not being able to access them, also known as nomophobia. This over-frequent use has also given way to cyber-loafing, the act of evading what is required to be done spending time leisurely on the mobile phone. Lim (2002, p. 678) defined cyberloafing as employees' voluntary use of their organizations' internet access for non-work purposes during work time or, more simply, the "IT way of idling on the job".

This study aims to determine the nomophobia levels of pre-service teachers, the variables that may affect their nomophobic behaviors, and the relationship between nomophobia and cyberloafing. The research questions that will lead the study towards its aims are:

1) To what extent do the pre-service teachers have nomophobia?

2) Is there a significant difference in nomophobia levels of the pre-service teachers due to their;
a. gender
b. department they study in
c. mobile technology usage experience
d. social media usage time?

3) Is there a significant relationship between the nomophobia levels and the cyberloafing levels of pre-service teachers?

\section{Method}

\subsection{Research Design}

In this study, the nomophobia levels of the pre-service teachers, the variables affecting by the nomophobia levels, and the relationship between the levels of nomophobia and cyberloafing were examined. This study was designed as a correlational study (Creswell, 2012), which allowed the researchers to evaluate the relationships and impacts among independent and dependent variables.

\subsection{Sample}

The study group consisted of 670 pre-service teachers who studied at a public university in Turkey and had completed Basic Information Technologies I and II courses successfully. The study was conducted in the spring semester of the academic year 2018-2019. The data obtained from 666 pre-service teachers were analyzed. The demographic information regarding the pre-service teachers is shown in Table 1. 
Table 1. Participants' demographic information

\begin{tabular}{|c|c|c|c|}
\hline \multirow[t]{3}{*}{ Gender } & & $\mathrm{N}$ & $\%$ \\
\hline & Female & 502 & 75.4 \\
\hline & Male & 164 & 24.6 \\
\hline \multirow[t]{5}{*}{ Class } & & $\mathbf{N}$ & $\%$ \\
\hline & 1 & 215 & 32.3 \\
\hline & 2 & 168 & 25.2 \\
\hline & 3 & 153 & 23 \\
\hline & 4 & 130 & 19.5 \\
\hline \multirow[t]{9}{*}{ Department } & & $\mathbf{N}$ & $\%$ \\
\hline & Primary Education & 115 & 17.3 \\
\hline & Early Childhood Education & 59 & 8.9 \\
\hline & Science Education & 97 & 14.6 \\
\hline & Elementary Mathematics Education & 60 & 9 \\
\hline & English Language Teaching & 93 & 14 \\
\hline & Physical Education and Sport Education & 83 & 12.5 \\
\hline & Turkish Language Teaching & 70 & 10.5 \\
\hline & Social Science Education & 89 & 13.4 \\
\hline \multirow[t]{7}{*}{ Mobile Technology Usage } & & $\mathbf{N}$ & $\%$ \\
\hline & Less than 1 year & 11 & 1.7 \\
\hline & $1-2$ Years & 29 & 4.4 \\
\hline & $2-3$ years & 44 & 6.6 \\
\hline & $3-4$ years & 76 & 11.4 \\
\hline & $4-5$ years & 126 & 18.9 \\
\hline & More than 5 years & 380 & 57.1 \\
\hline \multirow[t]{7}{*}{ Daily Social Networks Usage } & & $\mathbf{N}$ & $\%$ \\
\hline & Less than 1 hour & 42 & 6.3 \\
\hline & 1-2 Hours & 91 & 13.7 \\
\hline & 2-3 Hours & 146 & 21.9 \\
\hline & 3-4 Hours & 165 & 24.8 \\
\hline & 4-5 Hours & 91 & 13.7 \\
\hline & More than 5 Hours & 131 & 19.7 \\
\hline
\end{tabular}

\subsection{Research Instrument and Procedure}

The data of the study were collected by using a personal information form, the Nomophobia Scale (NMP-Q), and the Cyberloafing Scale. The Nomophobia Scale (NMP-Q) developed by Yildirım and Correia (2015) and adapted into Turkish by Yıldırım, Sumuer, Adnan and Yıldırım (2015) consists of a total of 20 items with responses given on the Likert type scale of 7 (1: Strongly Disagree, 7: Strongly Agree). The reliability coefficient of the original scale calculated using Cronbach's alpha was given as 0.95 and the reliability coefficient of the scale that was adapted to Turkish was given as 0.92 . The scale has four sub-dimensions: Inaccessibility to Information (4 items), Losing Connection (5 items), Failure to Communicate (6 items), and Inability to Feel Comfortable ( 5 items). The cyberloafing levels of the students in educational environments were measured using the "Cyberloafing Scale" (Akbulut, Dursun, Dönmez, \& Şahin, 2016). This scale is a 5-point Likert type which has values between "never" (1) and "always" (5), and which consists of 5 factors and 30 items. The factors of the scale consisted of "Sharing" (9 items), "Shopping" (7 items), "Real-time update" (5 items), "Access to online content" (5 items) and "Game" (4 items). The reliability coefficient of the scale calculated using Cronbach's alpha was given as 0.95 (Akbulut et al., 2016). In this study, Cronbach's Alpha value for the reliability of the Nomophobia scale was calculated as 0.944; Cronbach's Alpha value for the reliability of the cyberloafing scale was calculated as 0.964 . These values indicate that both scales have very high reliability (Nunally, 1978).

The personal information form, the Nomophobia Scale and the Cyberloafing Scale used within the scope of the research were applied to 670 pre-service teachers who had completed Basic Information Technologies I and II courses respecting the voluntariness principal and after necessary information was provided to them. 4 scales that were not filled in completely were not evaluated.

The data collected were analyzed using The Statistical Package for the Social Sciences 22.0 (SPSS 22.0). In the analysis process, statistical techniques such as mean, standard deviation, t-test, one-way analysis of variance (ANOVA), and regression analysis were used. An independent sample t-test was used to determine the 
nomophobia levels of pre-service teachers based on gender; one-way analysis of variance (ANOVA) was used to determine the nomophobia levels depending on their departments of study, mobile technology use experiences, daily social media use periods, and academic achievement, and regression analysis was facilitated to interpret the relationship between the nomophobia levels and the cyberloafing levels. Since the skewness and kurtosis coefficients of the data collected were within the range of +-2 , it was seen that parametric tests could be used since the data were suitable for normal distribution, an intermittent scale was used, and the variances were homogenous.

\section{Findings}

The study aims to define the relationship between the nomophobia levels of the pre-service teachers, the variables affecting the nomophobia levels, and the relationship between the levels of nomophobia and cyberloafing. The findings obtained for this purpose are discussed and presented under suitable headings for sub-purposes respectively.

\subsection{Findings Regarding Nomophobia Levels of Pre-Service Teachers}

The nomophobia levels of the participants were evaluated according to the scores obtained from the scale and arithmetic mean. The minimum score that can be obtained from the scale which consists of 20 expressions in the Likert type of 7 is 20 while the maximum score is 140 . The point range between $0-20$ shows there is no nomophobia, the range between 21-60 shows a low-level nomophobia, and the range between 61-100 points to a moderate level of nomophobia while the range between 101-140 signifies a high level of nomophobia. The nomophobia scores of pre-service teachers were calculated as 85 on average. It can be said that the nomophobia levels of the pre-service teachers were moderate. The nomophobia scores of the participants are shown in Table 2 .

Table 2. Nomophobia scores of pre-service teachers

\begin{tabular}{lll}
\hline Nomophobia scores & $\mathrm{f}$ & $\%$ \\
\hline High Level & 198 & 29.7 \\
Moderate Level & 330 & 49.6 \\
Low-level & 138 & 20.7 \\
\hline
\end{tabular}

When the scores of the participants were evaluated, it was seen that 528 students $(79.3 \%)$ had a moderate and high level of nomophobia while 138 students (20.7\%) had a low level of nomophobia. Table 3 shows the mean scores of pre-service teachers on basis of the items. 
Table 3. Mean scores of sub-dimensions of the Nomophobia Scale

\begin{tabular}{|c|c|c|c|}
\hline & Items & $\bar{x}$ & $\boldsymbol{\sigma}$ \\
\hline & Factor 1: Not Being Able to Access Information & & \\
\hline 1 & I would feel uncomfortable without constant access to information through my smartphone & 4.64 & 1.849 \\
\hline 2 & I would be annoyed if I could not look at information up on my smartphone when I wanted to do so. & 4.63 & 1.851 \\
\hline 3 & Being unable to get the news (e.g., happenings, weather, etc.) on my smartphone would make me nervous. & 4.66 & 1.911 \\
\hline 4 & $\begin{array}{l}\text { I would be annoyed if I could not use my smartphone and/or its capabilities when I wanted to do so } \\
\text { Factor 2: Losing Connectedness }\end{array}$ & 4.67 & 1.837 \\
\hline 5 & Running out of battery on my smartphone would scare me. & 4.56 & 2.064 \\
\hline 6 & If I were to run out of credits or hit my monthly data limit, I would panic. & 3.93 & 2.091 \\
\hline 7 & $\begin{array}{l}\text { If I did not have a data signal or could not connect to Wi-Fi, then I would constantly check to see if I had a } \\
\text { signal or could find a Wi-Fi network. }\end{array}$ & 4.46 & 1.963 \\
\hline 8 & If I could not use my smartphone, I would be afraid of getting stranded somewhere & 3.45 & 2.030 \\
\hline 9 & $\begin{array}{l}\text { If I could not check my smartphone for a while, I would feel a desire to check it. } \\
\text { Factor 3: Not Being Able to Communicate }\end{array}$ & 4.28 & 1.923 \\
\hline 10 & I would feel anxious because I could not instantly communicate with my family and/or friends. & 4.55 & 1.895 \\
\hline 11 & $\begin{array}{l}\text { If I didn't have my smartphone with me I would be worried because my family and/or friends could not } \\
\text { reach me }\end{array}$ & 4.85 & 1.808 \\
\hline 12 & I would feel nervous because I would not be able to receive text messages and calls. & 4.64 & 1.840 \\
\hline 13 & I would be anxious because I could not keep in touch with my family and/or friends & 4.74 & 1.834 \\
\hline 14 & I would be nervous because I could not know if someone had tried to get a hold of me. & 4.59 & 1.836 \\
\hline 15 & $\begin{array}{l}\text { I would feel anxious because my constant connection to my family and friends would be broken. } \\
\text { Factor 4: Giving Up Convenience }\end{array}$ & 4.57 & 1.876 \\
\hline 16 & I would be nervous because I would be disconnected from my online identity. & 3.42 & 1.917 \\
\hline 17 & I would be uncomfortable because I could not stay up-to-date with social media and online networks. & 3.52 & 1.930 \\
\hline 18 & $\begin{array}{l}\text { I would feel awkward because I could not check my notifications for updates from my connections and } \\
\text { online networks. }\end{array}$ & 3.50 & 1.924 \\
\hline 19 & I would feel anxious because I could not check my email messages. & 3.48 & 1.932 \\
\hline 20 & I would feel weird because I would not know what to do. & 3.63 & 2.025 \\
\hline
\end{tabular}

It was seen that the pre-service teachers obtained their lowest score from the item which is "I would be nervous because I would be disconnected from my online identity" $(\bar{x}=3.42)$ and the highest score from the item which is "If I didn't have my smartphone with me I would be worried because my family and/or friends could not reach me" $(\bar{x}=4.85)$. The mean scores of subscales are shown in Table 4 .

Table 4. Mean scores of subscales

\begin{tabular}{llll}
\hline Factors & Min. & Maks. & $\bar{x}$ \\
\hline Not being able to access information & 1 & 7 & 4.65 \\
Losing connectedness & 1 & 7 & 4.13 \\
Not being able to communicate & 1 & 7 & 4.65 \\
Giving up convenience & 1 & 7 & 3.51 \\
Total & 1 & 7 & 4.235 \\
\hline
\end{tabular}

When the subscales of the scale were examined, it was seen that the scores obtained from Not Being Able to Access Information $(\bar{x}=4.65)$, Losing Connectedness $(\bar{x}=4.13)$, Not Being Able to Communicate $(\bar{x}=4.65)$, Giving Up Convenience $(\bar{x}=3.51)$ were above the mean score.

\subsection{The Relationship Between Nomophobia Levels and Gender}

An independent sample t-test was used to determine whether the nomophobia level differed by gender. According to the Levene test, the variance was found to be homogeneous. Table 5 shows the gender effect on nomophobia levels of pre-service teachers.

Table 5. Nomophobia levels in terms of gender

\begin{tabular}{llllll}
\hline Gender & $\mathrm{N}$ & Mean & Std. Deviation & $\mathrm{T}$ & $\mathrm{P}$ \\
\hline Female & 502 & 4.396 & 1.309 & 5.394 & 0.000 \\
Male & 164 & 3.762 & 1.296 & & \\
\hline
\end{tabular}


In this case, it was determined that the t-test statistic was 5.394, the significance level $\mathrm{p}=0.000$, and nomophobia level differed by gender. When the averages were examined, it was found that the level of nomophobia was significantly higher in women than in men.

\subsection{The Relationship Between Nomophobia Levels and Class Variable}

A one-way analysis of variance (ANOVA) test was used to determine whether the level of nomophobia differed according to the class level of study. Nomophobia levels in terms of the class variable are shown in Table 6 .

Table 6. Nomophobia levels in terms of class variable

\begin{tabular}{llllll}
\hline & Sum of Squares & Df & Mean Square & F & Sig. \\
\hline Between Groups & 6.277 & 3 & 2.092 & 1.179 & 0.032 \\
Within Groups & 1174.888 & 662 & 1.775 & & \\
Total & 1181.165 & 665 & & & \\
\hline
\end{tabular}

As a result of the ANOVA test. it was determined that the level of nomophobia did not show a statistically significant difference according to the class level of study $(\mathrm{F} 3.662=1.179 ; \mathrm{p}<0.005)$.

\subsection{The Relationship Between Nomophobia Levels and Department}

An ANOVA test was used to determine whether the nomophobia level of the participants differed according to the department in which they studied. The relationship between nomophobia levels and department are shown in Table 7.

Table 7. Results of one-way analysis of variance according to the department

\begin{tabular}{llllll}
\hline & Sum of Squares & df & Mean Square & F & Sig. \\
\hline Between Groups & 24.968 & 7 & 3.567 & 2.039 & 0.049 \\
Within Groups & 1156.197 & 658 & 1.757 & & \\
Total & 1181.165 & 665 & & & \\
\hline
\end{tabular}

It was determined that the nomophobia levels of the participants studying in 8 different departments showed a significant difference depending upon their departments $(p=0.049)$. Tukey and Scheffe tests were performed to determine the difference between the levels of nomophobia between the departments, but it was determined that there was no significant difference between the departments based on the results of the analysis. However, this result contradicts the results of the ANOVA test. It is thought that this is because the ANOVA test indicated a statistically significant difference with a small difference.

\subsection{The Relationship Between Nomophobia Levels and Mobile Technology Experiences}

The ANOVA test was used to determine whether the nomophobia levels of the participants differed according to their smartphone experience (how many years they owned a smartphone). Mobile technology's effect on nomophobia levels are shown in Table 8.

Table 8. One-way ANOVA results based on mobile technology experience

\begin{tabular}{llllll}
\hline & Sum of Squares & df & Mean Square & F & Sig. \\
\hline Between Groups & 8.268 & 5 & 1.654 & 0.930 & .461 \\
Within Groups & 1172.897 & 660 & 1.777 & & \\
Total & 1181.165 & 665 & & & \\
\hline
\end{tabular}

As a result, one-way ANOVA test, it was observed that the nomophobia level did not show a significant difference given the mobile technology use experience of the participants (F5.660 $=0.930 ; p>0.005)$.

\subsection{Findings Regarding Daily Social Media Use}

A one-way ANOVA test was performed to determine whether the level of nomophobia showed a significant difference concerning daily social media use time. Daily social media use effect on nomophobia levels are shown in Table 9. 
Table 9. One-way analysis of variance according to daily social media use

\begin{tabular}{llllll}
\hline & Sum of Squares & df & Mean Square & F & Sig. \\
\hline Between Groups & 102.545 & 5 & 20.509 & 12.549 & .000 \\
Within Groups & 1078.620 & 660 & 1.634 & & \\
Total & 1181.165 & 665 & & & \\
\hline
\end{tabular}

As a result of the test, it was seen that the level of nomophobia significantly differed by their social media using time $(\mathrm{F} 5.660=12.549 ; \mathrm{p}<0.05)$. A Tukey test was used as Post-Hock analysis to determine how the time spent on social networks made a difference concerning the level of nomophobia. In cases in which the variance of the groups is homogeneous $(\mathrm{p}<0.05)$, the Tukey test is used to define the source of the difference. According to the Tukey test performed, a significant difference was discovered between pre-service teachers who spent less than 1 hour on social networks and pre-service teachers who spend 3 hours or more. It is seen that the analyzes show that as the time spent by pre-service teachers on social networks increases, the nomophobia levels also increase.

\subsection{Relationship Between Nomophobia and Cyberloafing}

The results of the regression analysis conducted to determine whether there is a relationship between the levels of nomophobia and cyberloafing of the pre-service teachers are presented in Table 10.

Table 10. Results of regression analysis

\begin{tabular}{|c|c|c|c|c|c|c|c|}
\hline & Model & $\mathrm{R}$ & R Square & Adjusted R Square & \multicolumn{3}{|c|}{ Std. Error of the Estimate } \\
\hline & 1 & $.213 \mathrm{a}$ & .045 & .440 & \multicolumn{3}{|c|}{1.30322} \\
\hline \multirow[t]{4}{*}{ ANOVA } & & Sum of Squares & Df & Mean Square & $\mathrm{F}$ & \multicolumn{2}{|l|}{ Sig. } \\
\hline & Regression & 53.436 & 1 & 53.436 & 31.463 & \multicolumn{2}{|l|}{0.000} \\
\hline & Residual & 1127.729 & 664 & 1.698 & & & \\
\hline & Total & 1181.165 & 665 & & & & \\
\hline \multirow[t]{4}{*}{ Coefficients } & & \multicolumn{2}{|c|}{ Unstandardized Coefficients } & $\mathrm{T}$ & Sig. & \multicolumn{2}{|c|}{ Collinearity Statistics } \\
\hline & & B & Std. Error & & & Tolerance & VIF \\
\hline & Constant & 3.484 & .144 & 24.222 & .000 & & \\
\hline & İndependent & .303 & .054 & 5.609 & .000 & 1.000 & 1.000 \\
\hline
\end{tabular}

When Table 10 is examined, it is seen that the model is statistically significant and that cyberloafing predicts the nomophobia levels of pre-service teachers significantly $(\mathrm{R} 2=0.045 ; \mathrm{F} 1.664=31.463 ; \mathrm{p}=0.000)$. This explains that the variance of the cyberloafing levels of pre-service teachers, which is an independent variable, to the nomophobia levels, which is a dependent variable is $4.5 \%$. The significance test of the coefficient of the independent variable in the regression equation $(\mathrm{B}=3.484)$ also shows that the cyberloafing level is a significant explanatory $(\mathrm{p}=0.000)$. Besides, the VIF value is less than 10 and that the Tolerance value is greater than 0.2 indicate that there is no multiple correlation problem. According to the results of the analysis, the regression equation is as follows:

Nomophobia Level $=3.484+(0.303 \times$ Cyberloafing level $)$

\section{Discussion, Conclusion and Recommendations}

With the rapid development in smartphone technologies, smartphones have become frequently used in our daily lives and make our lives easier. The intensive use of smartphones has brought about concepts such as problematic smartphone use, smartphone addiction, nomophobia, cyber-bullying, and cyberloafing. This study aims to determine the nomophobia levels of the pre-service teachers, the variables affecting the nomophobia levels, and the relationship between the levels of nomophobia and cyberloafing. The study, which was designed as a correlational study, was conducted with the voluntary participation of 666 pre-service teachers. The data of the study was collected via using a personal information form, the Nomophobia Scale (NMP-Q), and the Cyberloafing Scale.

The nomophobia scores of pre-service teachers were calculated as 85 on average. When the scores of the participants were evaluated, it was seen that 528 students $(79.3 \%)$ had a moderate and high level of nomophobia while 138 students $(20.7 \%)$ had a low level of nomophobia. It was found that the nomophobia levels of the pre-service teachers were above the mean score. This finding of the research is parallel to the ones in the 
literature (Yıldırım, Şumuer, Adnan, \& Yıldırım, 2016; Gezgin, Çakır, \& Yıldırım, 2016; Gezgin, Şahin, \& Y1ldirım, 2017). When the sub-dimensions of the scale were examined, it was seen that the pre-service teachers had the highest scores in the subscale named as Not Being Able to Access Information, which is similar to the study conducted by Yildirım et al. (2016). When the scores obtained based on items were examined, it was seen that the pre-service teachers obtained the highest score from the item called "If I didn't have my smartphone with me, I would be worried because my family and/or friends could not reach me".

As a result of the analyses conducted to determine whether the nomophobia levels of teacher trainees differ by gender, it was seen that the nomophobia level in women was statistically higher than that of men. When the studies examining whether the nomophobia level differed depending upon gender in the literature are examined, it was seen that these studies had reached different results. There are studies in which the nomophobia level differed depending on gender, which is parallel to the finding of this study, (Yıldırım et al., 2015; Gezgin \& Çakır, 2016; Erdem, Türel, \& Kalkın, 2017; Gezgin, Şahin, \& Yıldırım, 2017; Hoşgör, Tandoğan, \& Gündüz-Hoşgör, 2017; Kanmani, Bhavani, \& Maragatham, 2017; Sevim-Çırak \& İslim, 2020) as well as the studies in which nomophobia level did not show a significant difference related to gender (Dixit et al., 2010; Adnan \& Gezgin, 2016). Studies conducted in the context of gender may vary depending on societies, cultures, and working groups. In addition, TUIK 2018 Household Information Technology (IT) Usage Survey results indicated that while the internet use rate was $80.4 \%$ for men in the 16-74 age group, it was $65.5 \%$ for women. Based on these results, it is seen that the rate of internet use of women is lower than men, whereas their nomophobia levels are higher.

It was concluded that the nomophobia levels of the pre-service teachers did not differ regarding the level of class. This finding of the research is similar to the result of the study conducted by Deniz and Gezgin (2016). Although it was concluded that the nomophobia levels of the pre-service teachers differed significantly to the departments in which they studied, no significant difference was found among the departments. This finding of this study is similar to the study conducted by Hoşgör, Tandoğan and Gündüz-Hoşgör (2017). It was seen that the nomophobia levels of the pre-service teachers did not differ concerning their experience of using smartphones (how many years they owned smartphones). Adnan and Gezgin (2016), similar to the findings of the study, concluded that the nomophobia levels of university students did not show a significant difference related to the duration of owning a smartphone. Similarly, Gezer, Şahin and Yıldırım (2017) found in the study conducted with social network users that nomophobia levels did not show a significant difference in relation to the duration of having a smartphone. However, there are also studies concluding that smartphone experiences are related to the level of nomophobia (Yıldırım \& Correia, 2015; Yıldırım et al., 2016).

It was concluded that the nomophobia levels of the pre-service teachers differed significantly according to the daily social media usage time. Significant differences were found between pre-service teachers who spent less than 1 hour and the ones who spent 3 hours or more on social networks. The analyzes showed that as the time spent by pre-service teachers on social networks increased, their nomophobia levels increased, too.

As the last finding of the study, it was concluded that cyberloafing significantly predicted nomophobia levels of pre-service teachers. Based on this result, it can be said that the pre-service teachers' cyberloafing behaviors will increase their tendency to exhibit nomophobic behaviors. In the literature review, there was no study examining the relationship between nomophobia and cyberloafing, but according to the results of a study conducted with 598 university students by Gökçearslan, Mumcu, Haşlaman and Çevik (2016), cyberloafing had an endorsing effect on smartphone addiction.

When interpreting the results of the study, a few limitations should be taken into consideration. In this study, data were collected from a single university. For further research, new research can be conducted by collecting data from different universities and cultures across the country. Quantitative research methods were used in this study. For further research, mixed studies in which qualitative methods are also taken advantage of can be designed to obtain more in-depth data. There are a limited number of studies in the literature to determine the variables affecting the nomophobia levels of pre-service teachers in private and the young population in general. Studies using different variables will contribute to the literature. Determining the variables affecting nomophobia levels, which are observed to be increasing rapidly among the young population and negatively affecting business life and private life, has gained importance both in terms of contributing to the literature and taking necessary measures against it. In this study, it was observed that the nomophobia levels of the pre-service teachers were related to gender, time spent on social networks and cyberloafing behaviors. It is thought that the regulation of the use of smartphones and social networks in a way to support educational processes may turn this situation, which adversely affects academic achievement, into an advantage. 


\section{References}

Adnan, M., \& Gezgin, D. M. (2016). Modern çağın yeni fobisi: üniversite öğrencileri arasında nomofobi prevalansı. Ankara Üniversitesi Eğitim Bilimleri Fakültesi Dergisi, 49(1), 141-158. https://doi.org/10.1501/Egifak_0000001378

Akbulut, Y., Dursun, Ö. Ö., Dönmez, O., \& Şahin, Y. L. (2016). In search of a measure to investigate cyberloafing in educational settings. Computers in Human Behavior, 55, 616-625. https://doi.org/10.1016/j.chb.2015.11.002

Billieux, J., Maurage, P., Lopez-Fernandez, O., Kuss, D. J., \& Griffiths, M. D. (2015). Can disordered mobile phone use be considered a behavioral addiction? An update on current evidence and a comprehensive model for future research. Current Addiction Reports, 2, 156-162. https://doi.org/10.1007/s40429-015-0054-y

Billieux, J., Philippot, P., Schmid, C., Maurage, P., De Mol, J., \& Van der Linden, M. (2015). Is dysfunctional use of the mobile phone a behavioral addiction? Confronting symptom - based versus process - based approaches. Clinical Psychology and Psychotherapy, 22(5), 460-468. https://doi.org/10.1002/cpp.1910

Bragazzi, N. L., \& Pente, G. D. (2014). A Proposal for Including Nomophobia in The New DSM-V. Psychology Research and Behavior Management, 7, 155-160. https://doi.org/10.2147/PRBM.S41386

Burucuoğlu, M. (2017). Meslek yüksekokulu öğrencilerinin nomofobi düzeyleri üzerinde bir araştırma. Karabük Üniversitesi Sosyal Bilimler Enstitüsü Dergisi, 7(2), 482-489. https://doi.org/10.14230/joiss423

Creswell, J. W. (2012). Educational research: planning. Conducting, and Evaluating.

Dixit, S., Shukla, H., Bhagwat, A., Bindal, A., Goyal, A., Zaidi, A. K., \& Shrivastava, A. (2010). A study to evaluate mobile phone dependence among students of a medical college and associated hospital of central India. Indian Journal of Community Medicine: Official Publication of Indian Association of Preventive \& Social Medicine, 35(2), 339-341. https://doi.org/10.4103/0970-0218.66878

Gezgin, D. M., \& Çakır, Ö. (2016). Analysis of nomofobic behaviors of adolescents regarding various factors. Journal of Human Sciences, 13(2), 2504-2519. https://doi.org/10.14687/jhs.v13i2.3797

Gezgin, D. M., Çakır, Ö., \& Yıldırım, S. (2016). Ergenler arasında nomofobi yaygınlık düzeyi ile internet bağımlılığının ilişskisi. 3.Uluslararası Avrasya Eğitim Araştırmaları Kongresi, Muğla-Turkey. Retrieved from https://ejercongress.org/pdf/bildirikitabi2016_ejer.pdf

Gezgin, D., Şahin, Y., \& Yıldırım, S. (2017). Sosyal ağ kullanıcıları arasında nomofobi yaygınlığının çeşitli faktörler açısından incelenmesi. Eğitim Teknolojisi Kuram ve Uygulama, 7(1), 1-15. https://doi.org/10.17943/etku.288485

Global Digital Report. (2019). Retrieved August 1, 2019, from https://wearesocial.com/global-digital-report-2019

Gökçearslan, Ş., Mumcu, F. K., Haşlaman, T., \& Çevik, Y. D. (2016). Modeling smartphone addiction: The role of smartphone usage, self-regulation, general self-efficacy and cyberloafing in university students. Computers in Human Behavior, 63, 639-649. https://doi.org/10.1016/j.chb.2016.05.091

Hong, F.-Y., Chiu, S.-I., \& Huang, D.-H. (2012). A model of the relationship between psychological characteristics, mobile phone addiction and use of mobile phones by Taiwanese university female students. Computers in Human Behavior, 28(6), 2152-2159. https://doi.org/10.1016/j.chb.2012.06.020

Hoşgör, H., Tandoğan, Ö., \& Gündüz-Hoşgör, D. (2017). Nomofobinin günlük akıllı telefon kullanım süresi ve okul başarısı üzerindeki etkisi: Sağlık personeli adayları örneği. Akademik Sosyal Araştırmalar Dergisi, 5(46), 573-595. https://doi.org/10.16992/ASOS.12266

Kanmani, A., Bhavani, U., \& Maragatham, R. S. (2017). NOMOPHOBIA-An Insight into Its Psychological Aspects in India. Int J Indian Psychol, 4(2), 5-15.

King, A. L. S., Valença, A. M., Silva, A. C. O. et al. (2013) Nomophobia: Dependency on virtual environments or social phobia? Computers in Human Behavior, 29(1), 140-144. https://doi.org/10.1016/j.chb.2012.07.025

Lim, V. K. G. (2002). The IT way of loafing on the job: cyberloafing, neutralizing and organizational justice. Journal of Organizational Behaviour, 23, 675-694. https://doi.org/10.1002/job.161

Lin, Y. H., Chang, L. R., Lee, Y. H., Tseng, H. W., Kuo, T. B., \& Chen, S. H. (2014). Development and validation of the Smartphone Addiction Inventory (SPAI). PloS One, 9(6), e98312. https://doi.org/10.1371/journal.pone.0098312 
Nagpal, S. S., \& Kaur, R. (2016). Nomophobia: the problem lies at our fingertips. Indian J. Public Health W., 12, $1135-1139$. Retrieved from http://eds.b.ebscohost.com/eds/pdfviewer/pdfviewer?vid=5\&sid=5732b418-90ce-44ff-ba48-bec4c6edf172 \%40pde-v-sessmgr01

Nunnally, J. C. (1978). Psychometric theory (2nd ed., p. 416). McGraw-hill. Hillsdale, NJ.

Pavithra, M. B., Suwarna, M. M., \& Murthy, T. S. (2015). A Study on nomophobia-mobile phone dependence, among students of a medical college in Bangalore. Ntl J of Community Med, 6(3), 340-344. Retrieved from http://njcmindia.org/uploads/6-3_340-344.pdf

Sevim-Cirak, N., \& Islim, O. F. (2020). Investigation into Nomophobia amongst Turkish pre-service teachers. Education and Information Technologies, 1-19. https://doi.org/10.1007/s10639-020-10335-9

Spitzer, M. (2015). M-Learning? When it comes to learning, smartphones are a liability, not an asset. Trends in Neuroscience and Education, 4, 87-89. https://doi.org/10.1016/j.tine.2015.11.004

TUiK Hane Halkı Bilişim Teknolojileri (BT). (2019). Kullanım Araştırması. Retrieved August 1, 2019 from http://www.tuik.gov.tr/PreHaberBultenleri.do?id=27819

Turan, E. Z., \& Becit, İ. G. (2018). İlahiyat fakültesi öğrencilerinin nomofobi düzeylerinin çeşitli faktörler açısından incelenmesi. OPUS Uluslararası Toplum Araştırmaları Dergisi, 9(16), 1931-1950. https://doi.org/10.26466/opus.461523

Türen, U., Erdem, H., \& Kalkın, G. (2017). Mobil Telefon Yoksunluğu Korkusu (Nomofobi) Yayılımı: Türkiye'den Üniversite Öğrencileri ve Kamu Çalışanları Örneklemi. Bilişim Teknolojileri Dergisi, 10(1), 1-10. Retrieved from https://dergipark.org.tr/tr/pub/gazibtd/issue/27536/289670

Y1ldırım, C. (2014). Exploring the dimensions of nomophobia: Developing and validating a questionnaire using mixed methods research. Graduate Theses and Dissertations. 14005. https://lib.dr.iastate.edu/etd/14005

Yıldırım, C., \& Correia, A. P. (2015). Exploring the dimensions of nomophobia: Development and validation of a self-reported questionnaire. Computers in Human Behavior, 49, 130-137. https://doi.org/10.1016/j.chb.2015.02.059

Yıldırım, C., Sumuer, E., Adnan, M., \& Yıldırım, S. (2015). A growing fear: Prevalence of nomophobia among Turkish college students. Information Development, 32(5), 1322-1331. https://doi.org/10.1177/0266666915599025

\section{Copyrights}

Copyright for this article is retained by the author, with first publication rights granted to the journal.

This is an open-access article distributed under the terms and conditions of the Creative Commons Attribution license (http://creativecommons.org/licenses/by/4.0/). 